http://dx.doi.org/10.4314/jae.v19i2.12

\title{
Determinants of Perceived Health and Environmental Effects of Fuelwood Exploitation among Farm Families in Ogun State, Nigeria
}

\author{
Odunuga Azeez Oluwagbenga \\ Department of Agricultural Extension and Rural Development \\ University of Ibadan. \\ Email: azeezodunuga@gmail.com
}

\author{
Akinbile, L. A. \\ Department of Agricultural Extension and Rural Development \\ University of Ibadan. \\ Email: lakinbile@yahoo.com \\ Phone: 08023250454
}

\begin{abstract}
The determinants of perceived health and environmental effect of fuelwood exploitation among farm families were examined in Ogun state, Nigeria. The sample comprises of farm families who exploit fuelwood in substantial proportion. Questionnaire was administered to one hundred and twenty respondents to obtain primary data and data was analysed using descriptive and inferential statistical tools. Results revealed that $48.3 \%$ of the respondents were within their active age of 35 to 41 years, $85.8 \%$ were male, $90.8 \%$ were married and $84.2 \%$ had primary education. Male members of farm families exploit fuelwood more than female for economic reasons. The majority (60.0\%) had unfavourable attitude towards fuelwood exploitation, while $62.5 \%$ had favourable perception on health effect of fuelwood exploitation. Also, 59.2\% had low knowledge about the environmental effects of fuelwood exploitation, while $63.3 \%$ of the farm families had high involvement in fuelwood exploitation. Also, $51.7 \%$ had negative perception of environmental effects of fuelwood exploitation. Significant contribution was recorded of sex, household size and knowledge of the effect of fuelwood exploitation on their perception of environmental and health effects of fuelwood exploitation with the coefficient of 0.022 , 0.006 and 0.000 respectively in the study area.
\end{abstract}

Respondents engaged in exploitation of fuelwood, irrespective of their personal characteristics, despite having knowledge of the environmental problems associated with its exploitation. It is recommended that farm families should be sensitized by environmental extension experts fully empowered by government on how to make the environment a conducive and hazard free one.

Keywords: Environmental effects, health effects, fuelwood exploitation, farm families 


\section{Introduction}

Forests are widely recognized as a source of various essential goods and services (DWAF, 2005). They protect the soil from erosion, maintain rates of evapo-transpiration and increase the soil's infiltration capacity (Morgan, 1995). In addition to the physical contribution to the environment, forests also provide ecological, economic, social, religious and cultural benefits (Mainagwa, 2010). However, a number of human activities have led to destruction and general decrease of existing forests. Of the myriad of causes of depletion of forests, increasing fuel wood usage has been identified as one of the biggest threat to forest covers. Over $80 \%$ of rural dwellers use fuel wood as a primary or secondary energy source (Hassan, Mbuli and Dlamini, 2002).

Approximately 2.5 to 3.0 billion people (40 to 50 percent of the world's total) rely on wood for fuel, both for warmth and food preparation. In Africa, wood is depended upon for up to $58 \%$ of all energy requirements and in many savannah areas, demand for wood supplies far exceeds the rate of growth (Williams, 2003). However, wood is more flexible than other energy sources and thus gains supremacy over other fuel resources mainly because it costs less and in some circumstances is obtained free from the environment.

Over-reliance on these fuelwood is a major cause of woodland and severe forest degradation where such degradation often leads to unintended environmental consequences that include among others biodiversity loss, physical land degeneration, and deforestation, environmental collapse associated with drought, flood and other extreme climatic changes. A study by Tee et al, (2009) in Nigeria showed that excessive fuel wood harvesting led to massive soil erosion, decreased water quality and dam siltation. These changes lie at the heart of fuel wood problems and set clear limits on the opportunities open to confront the problems effectively like irregular planting season due to climate change, bad roads due to erosion and flood, poor yield and low income due to loss of soil nutrients which leads to the loss of our forest cover needed for agricultural and other beneficial uses like grazing, and hunting.

This study, focused on the determinants of perceived environmental and health effect of fuelwood exploitation among farm families in Ogun state with the following objectives:

1. identify the personal characteristics of the respondents in the study area,

2. determine respondent's attitude towards fuelwood exploitation in the study area,

3. ascertain respondents' perception of the health effects of fuelwood exploitation in the study area, 
4. determine respondents' level of knowledge on the effect of fuelwood exploitation in the study,

5. determine respondents' rate of involvement in fuelwood exploitation in the study area, and

6. ascertain respondents' perception of the environmental effect of fuelwood exploitation in the study areas.

\section{Methodology}

The study area, Ogun state lies in the southern part of the country within $7^{0} 00^{\prime} \mathrm{N} 3^{0} 35^{\prime} \mathrm{E}$ neighboured by Oyo, Ondo and Lagos. The state which has Abeokuta as its capital has a land is of about 1,640,926 square kilometres. The projected population of Ogun state was estimated at 4,054,272 (NPC, 2006). The natural resources include chalk, phosphate and gravel. The vegetation in Ogun state ranges from derived savannah to rain forests. Its land area consists of natural resources such as forest reserves, river rocks, mineral deposits as well as extensive fertile soil suitable for cultivation of a wide range of equatorial, tropical and savannah crops.

The state is made up of Yorubas and is divided into four zones namely the Egbas, Yewas, ljebus, and Remos. The main food crops grown include cassava, maize, yam, rice, cocoyam and vegetable. Other crops like cocoa, coffee, kolanut, rubber, and oil palm are also produced. The sample for this study comprised of all farm families that engaged in fuelwood exploitation which include those that fell trees, involved in sale of fuelwood and uses wood as fuel for cooking. Ten percent of the twenty local governments were randomly selected (Ijebu north and Yewa north) and sixty structured questionnaire was administered to sixty respondents from each local government using an interview schedule to give a total of 120 respondents. Descriptive and inferential statistics were used for the analysis. Dependent variable was operationalized using a 5 point Likert-type scale of Strongly Agree (SA), Agree $(A)$, Undecided (U), Disagree (D) and Strongly Disagree (SD) in which the pooled mean was used to determined positive and negative effects of fuelwood exploitation.

\section{Results and Discussion}

The personal characteristics of the respondents on perceived environmental and health effect of fuelwood exploitation revealed the following:

The result on Table 1 revealed that the majority $(48.3 \%)$ of the respondents were young between the ages of 35 and 41 years, $27.5 \%$ were middle aged between the ages of 42 and 48 years. Also, $2.5 \%$ of them were old between the ages of $56-62$ years. The mean age of $41.2 \pm 6.4$ years implies that majority of the respondents were young and still possess enough strength, vigour and vitality to exploit fuelwood in a substantial amount. This is in accordance with the findings of Onasanya (2005) who asserted that most of the people who engaged in forestry activities were within their active age bracket. 
Table 1 also shows that the majority (85.8\%) of the respondents were male, while $14.2 \%$ of them were female. This implies that although fuelwood exploitation in the study area is been carried out by both sexes, most of it were being done by male. This negate the findings of Minibas (1997) who reported that rural women are more involved in fuelwood exploitation than male and that fuelwood exploitation activities were gender specific. This may mean that while the female exploit it for domestic use, the male exploit it for commercial purpose.

Income of respondents on Table 1 indicate that the majority (74.2\%) earn between $\mathrm{N} 10,000$ and $\mathrm{N} 20,000$ monthly, $14.2 \%$ earn between $\mathrm{N} 20,000$ and N30,000 monthly, $7.5 \%$ earn above N30,000, while $4.2 \%$ of them earn below N10,000 monthly. This implies that the majority of the rural dwellers lack assets and skills, and were unable to invest in high income generating activities, thereby remaining poor. This may make them exploit fuelwood on a regular basis. This is in line with the study of Baland and Platteau (1996) that high inequality of income exacerbate pressure on common pool resources resulting in consequent degradation of natural resources, lkurekong, et al. (2009) also found that local fuel exploitation was mostly prevalent in communities with low income, while Obua et al. (2010) found that overexploitation and unsustainable woodland exploitation is mainly prevalent in poorer communities.

Table 1 also shows that, the majority (57.5\%) of the respondents fell within the range of 5-6 members in their households. Also, 39.2\% of them fell within 3-4 members, while $3.3 \%$ of them fell within the range of $7-8$ members in their household. Mean 4.8 of household size implies that most of the respondents have more than two members to cater for in their households which may make them exploit fuelwood on a daily basis. This corroborates the finding of (Adhikari, (2002) and Baland et al., (2004) that intensity of forest products exploitation has been found to have a direct relation to household size.

Figure 1 further shows that, the majority (90.8\%) of the respondents were married, $5.8 \%$ were single, $2.5 \%$ were divorced, while $0.8 \%$ of were widow. This implies that the majority of the respondents being married have more responsibilities to cater for which could make them engage more in fuelwood exploitation to meet their family needs. This is in line with the findings of Adedoyin et al (2005) who reported that over $70 \%$ of rural people who engaged in fuelwood exploitation were married.

Figure 2 indicates that the majority $(84.2 \%)$ of the respondents had primary education, $11.7 \%$ had secondary education, $0.8 \%$ of them had tertiary education, while $3.3 \%$ had no formal education This implies that most of the respondents had low education but that alone cannot be considered as a major factor influencing fuelwood exploitation as most of the respondents had one form of education. This finding is in line with that of FAO (1999) that reported lack of education as a barrier for proper skills, abilities, being adoption prone, and a catalyst for poverty and low standard of living. 
Figure 3 shows that the majority of the respondents $(66.7 \%)$ engaged in farming, $16.7 \%$ in petty trading, $15.0 \%$ were artisans, while $1.7 \%$ of them engage in civil service. This implies that farming being the major primary occupation of the people is typical of a rural environment which can predispose the people to exploiting the forest on a daily basis. This is in line with the findings of Ebe, (2006) who noted that fuelwood trading is a very profitable business.

\section{Table 1: Distribution of households based on personal characteristics}

\begin{tabular}{lc}
\hline Variables & Percentage $(\%)(\mathrm{n}=120)$ \\
\hline & \\
Age & 10.0 \\
$28-34$ & 48.3 \\
$35-41$ & 27.5 \\
$42-48$ & 11.7 \\
$49-55$ & 2.5 \\
$56-62$ & \\
Mean = 41.2 & \\
S.D =6.4 & \\
Sex & \\
Male & 85.8 \\
Female & 14.2 \\
Monthly income & \\
Below 10,000 & 4.2 \\
10,000-20,000 & 74.2 \\
20,000-30,000 & 14.2 \\
Above 30,000 & 0.8 \\
Household size & \\
3-4 & 39.2 \\
7-6 & 57.5 \\
Mean= 4.8 & 3.3 \\
S.D=0.9 & \\
Source: Field survey, 2014 &
\end{tabular}

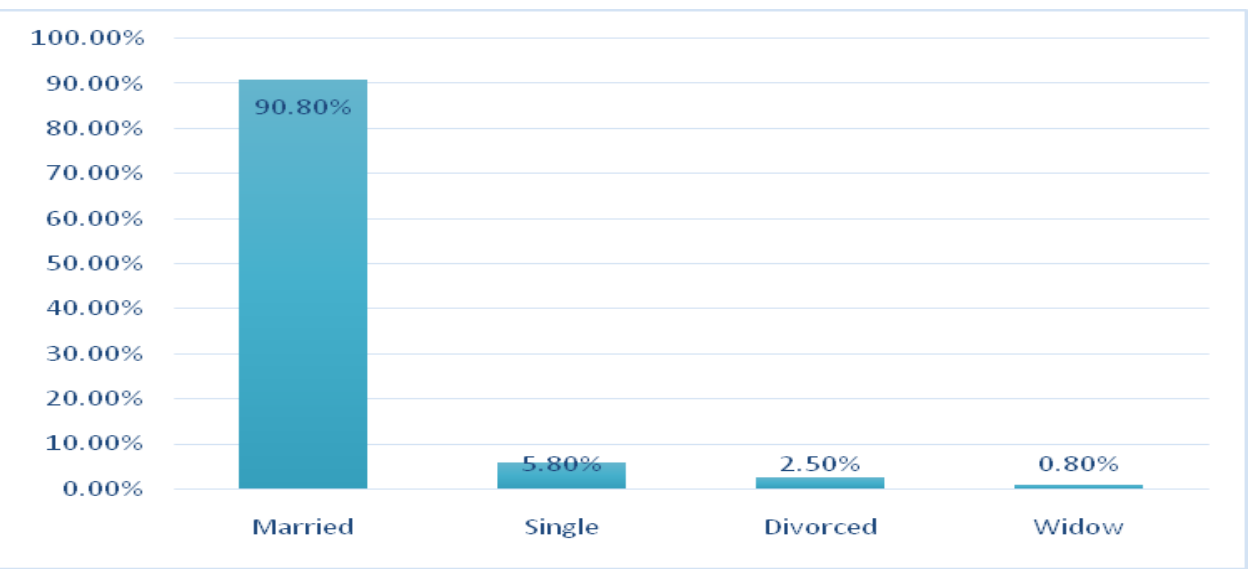

Figure 1: Distribution of respondents based on marital status Source: Field survey, 2014 
Creative commons User License: CC BY-NC-ND

Abstracted by: EBSCOhost, Electronic Journals Service (EJS),

Google Scholar, Directory of Open Access Journals (DOAJ),

Journal Seek, Scientific Commons, and

Food and Agricultural Organization (FAO)
Journal of Agricultural Extension

Vol. 19 (2) December, 2015

ISSN(e): 24086851; ISSN(Print); 1119944X

http://journal.aesonnigeria.org

http://www.ajol.info/index.php/jae

Email: editorinchief@aesonnigeria.org

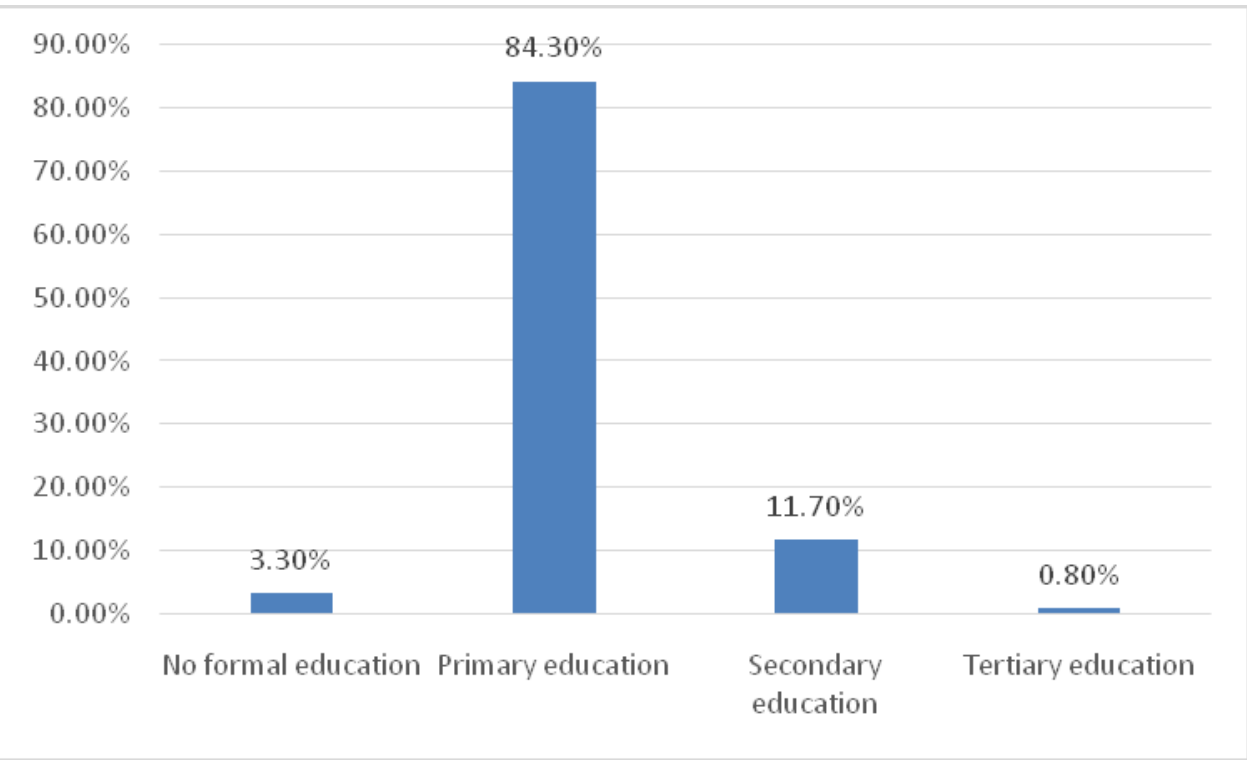

Figure 2: Distribution of respondents based on level of education Source: Field survey, 2014

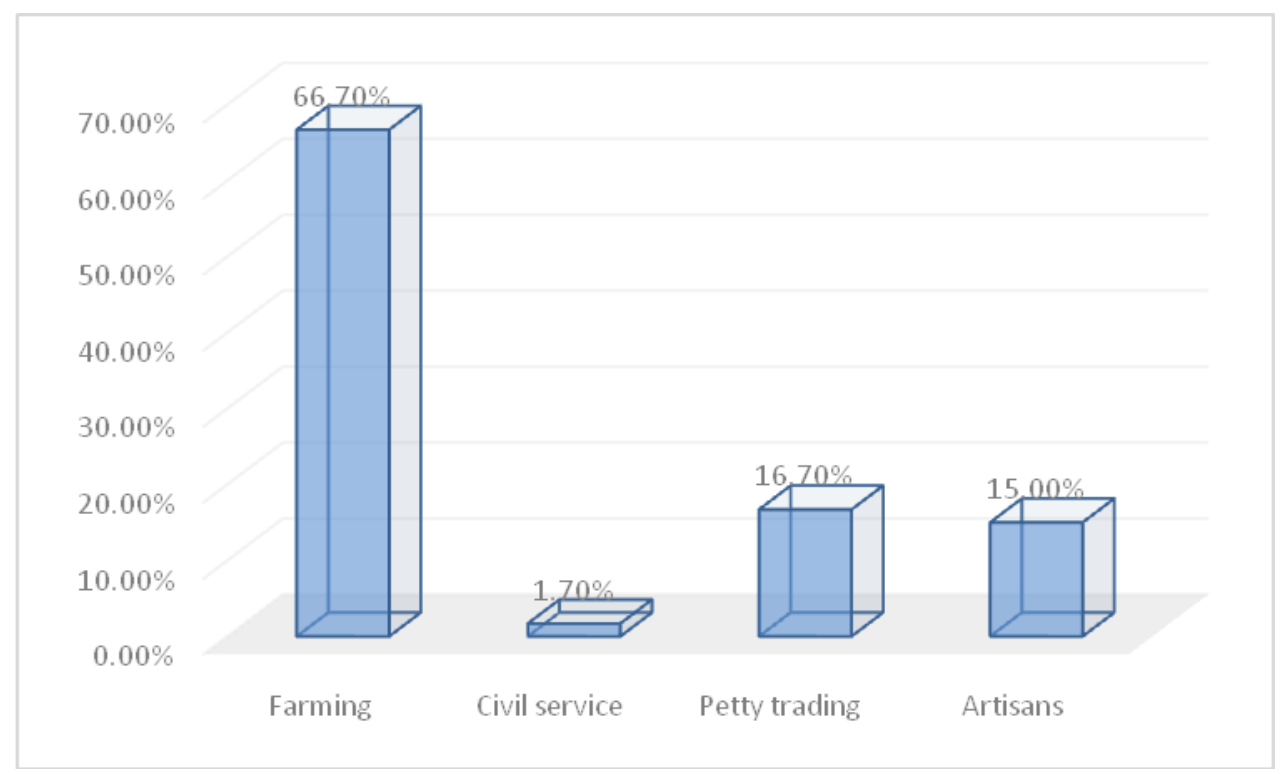

Figure 3: Distribution of respondents based on primary occupation Source: Field survey, 2014 


\section{Respondents' attitude towards fuelwood exploitation}

Table 2 shows that the majority $(60.0 \%)$ of the respondents had an unfavourable attitude towards the fuelwood exploitation while $40.0 \%$ had a favourable attitude towards its exploitation. This implies that as far as farm families see the forest as being a renewable resource that will naturally regenerate as much as exploited, they will continue to display an unfavourable attitude towards the threat its exploitation can pose to environmental stability which could lead to flooding, erosion, desertification, change in climate whereby if there is adequate control and balancing of deforestation and afforestation would reduce the problems faced.

Table 2: Distribution of attitude of rural dwellers towards the environment

\begin{tabular}{ll}
\hline Attitude & percentage $(\%)(\mathbf{n}=120)$ \\
Favourable $(43-51)$ & 40.0 \\
Unfavourable $(52-68)$ & 60.0 \\
Total & 100.0 \\
\hline
\end{tabular}

Mean $=51$, Minimum $=43$, Maximum $=68$

Source: Field survey, 2014

\section{Respondents' perception on health effects of fuelwood exploitation}

Table 3 shows that the majority $(62.5 \%)$ of the respondents had high perception on health effect of fuelwood exploitation, while $37.5 \%$ had low perception. This implies that most of the respondents knew about the health effect that might occur if they exploit fuelwood but still exploit it regularly based on the fact that it is their source of income, and possess a family to cater for. However, this revealed that respondents in this study are desperate to survive and this could expose them to risk and untimely death if sensitisation on health issues and capacity building which could empower them to diversify into other environmental friendly livelihood activities is not given to them.

\section{Table 3: Distribution of respondents based on perception on health effects of fuelwood exploitation}

\begin{tabular}{ll}
\hline Perceived health effect & percentage $(\%)(\mathbf{n}=120)$ \\
\hline Unfavourable $(1-19)$ & 37.5 \\
& \\
Favourable $\quad(20-28)$ & 62.5 \\
Total & 100.0 \\
\hline
\end{tabular}

Mean $=19$, Minimum = 1, Maximum $=28$

Source: Field Survey, 2014 


\section{Respondents' level of knowledge on perceived environmental effect of fuelwood exploitation}

Table 4 shows that more $(59.2 \%)$ of the respondents had low knowledge about the environmental effect of fuelwood exploitation, while $40.8 \%$ of them had a high knowledge about the effect of fuelwood exploitation. This implies that the respondents having a low knowledge about the effect of fuelwood exploitation can be pre-dispose to exploiting fuelwood more without considering the adverse effect it can have on sustaining the forest resources and maintaining a pleasant environment. However, these effects could lead to total destruction of the environmental resources but if prompt attention is given to add on to the knowledge of the respondents on the effects over-exploitation of fuelwood could pose to the environment, sustainability and a conducive environment would be attained.

Table 4: Distribution of respondents based on their level of knowledge on environmental effects of fuelwood exploitation

\begin{tabular}{ll}
\hline Knowledge & Percentage $(\%)(\mathbf{n}=\mathbf{1 2 0})$ \\
\hline Low $(2-5)$ & 59.2 \\
High (6-12) & 40.8 \\
Total & 100.0 \\
\hline \multicolumn{2}{l}{ Mean= 5, Minimum= 2, Maximum=12. Source: Field Survey, 2014}
\end{tabular}

\section{Respondents rate of involvement in fuelwood exploitation}

Table 5 shows that the majority $(63.3 \%)$ of the respondents had a high involvement in fuelwood exploitation, while $36.7 \%$ had low involvement. This implies that as far as farm families continue to see the forest as a means of survival, they will continue to exploit the forest on a regular basis, thereby pre disposing the forest to threat. This could be as a result of the high poverty level among farm families as they would want to provide for their family needs but if the respondents could be empowered with various support services which can make them go into other sources of income can help reduce the threat on the forest thereby enhancing environmental sustainability.

\section{Table 5: Distribution of rate of involvement of rural dwellers in fuelwood exploitation}

\begin{tabular}{ll}
\hline Involvement & Percentage $(\%)(\mathbf{n}=120)$ \\
\hline Low $(3-13)$ & 36.7 \\
High $(14-16)$ & 63.3 \\
Total & 100.0 \\
\hline
\end{tabular}

Mean $=13$, Minimum = 3, Maximum $=16$

Source: Field Survey, 2014 


\section{Respondents' perception on environmental effect of fuelwood exploitation}

Table 6 shows that $51.7 \%$ of the respondents had negative perception on environmental effects of fuelwood exploitation, while $48.3 \%$ had positive perception. This implies that irrespective of the fact that most of the respondents knew of the negative effects of uncontrolled fuelwood exploitation, they still exploit it based on their own personal interest and benefits. This finding agrees with the work of Jande (2005) who noted that over 50\% of the forest cover has been deforested for fuelwood and timber production. This uncontrolled fuelwood exploitation has place a dent on the sustainability of forest resources thereby increasing migration and loss of forest habitats whereas encouraging tree planting among farm families could reduce this effect posed by uncontrolled fuelwood exploitation. Also, orientating and enlightening farm families on the how to relate positively with the environment would help reduce over-exploitation of forest resources.

Table 6: Distribution of respondents based on their perception on environmental effect of fuelwood exploitation

\begin{tabular}{ll}
\hline Perceived Effect & Percentage $(\%)(\mathbf{n}=120)$ \\
\hline Negative $(37-48)$ & 51.7 \\
Positive $(49-68)$ & 48.3 \\
Total & 100.0
\end{tabular}

Mean $=48$, Minimum $=37$, Maximum $=68$

Source: Field Survey, 2014

\section{Contribution of independent variables to the perceived effect of environmental and health effect of fuelwood exploitation}

Regression analysis was conducted on the variables to determine the contributions of each selected independent variable to perception of environmental effect of fuelwood exploitation by the rural dwellers. Table 7 shows a $\mathrm{R}^{2}$ value of 0.277 revealing that the variables in the regression model put together could explain $27.7 \%$ of the variance in respondents' perception of effect of fuelwood exploitation.

The table further shows that three of the variables significantly predicted respondents' perception of environmental effect of fuelwood exploitation. These 
are: sex (Beta=-0.253), household size (Beta=0.270) and knowledge (Beta=0.382 ) respectively. All these had a direct influence on environmental effect of fuelwood exploitation. This implies that sex, household size and knowledge of the respondents contributes to the exploitation of fuelwood as most of the respondents being male, having more than two people to cater for and having some level of knowledge of the environmental effects of fuelwood exploitation could be the reason they exploit fuelwood on regular basis. This can be controlled if adequate effort is rendered to increase the poverty level of farm families in the study environment.

Table 7: Contribution of independent variables to the perceived environmental effects of fuelwood exploitation

\begin{tabular}{lcc}
\hline Variable & Beta & $\mathbf{T}$ \\
\hline & -0.132 & -1.210 \\
Age & -0.253 & $-2.328^{\star}$ \\
Sex & 0.096 & 0.998 \\
Marital status & 0.103 & 1.105 \\
Monthly income & 0.270 & $2.783^{\star}$ \\
Household size & 0.114 & 1.143 \\
Level of education & 0.171 & 1.533 \\
Primary occupation & & \\
& -0.118 & -1.380 \\
Health effect & -0.085 & -0.999 \\
Attitude & -0.382 & $-4.274^{\star}$ \\
Knowledge & -0.035 & -0.406 \\
Involvement & & \\
\hline
\end{tabular}

${ }^{*} P \leq 0.05$. Adjusted $R^{2}=0.203 ; S . E=0.448, P<0.05$

Source: Field survey, 2014

\section{Conclusion and Recommendation}

Based on the findings of the study, it can be concluded that farm families who engaged in fuelwood exploitation had unfavourable attitude, negative perception towards the environment but possess some level of knowledge of the environmental effects and health effects associated with exploitation of fuelwood. However, the forest is exploited on a regular basis by farm families due to the fact that it is their major source of income and a means to meet their daily needs thereby bringing a threat to forest resources, human health and a change in the atmospheric condition of the environment (global warming).

Based on the conclusion of the study, the following recommendations were made:

1. Alternative source of fuel such as kerosene, gas, and solar stoves should be made readily available to farm families at subsidized and affordable price in order to reduce the threat on the forest 
2. Better forest management practices such as creating of disciplined forest supervisory teams, forest extension services, good leadership among staffs and enforcement of tree planting should be encouraged in order to create a balance between the rate of deforestation and afforestation

3. Farm families should be sensitized by environmental extension experts fully empowered by government on the conservation of forest resources for its sustainability

4. Existing forest needs to be identified and protected to enhance appropriate monitoring of all activities in the forest

\section{References}

Adedoyin, S.F. S.K. Sanwo and Odunnaiya O. (2006). Fuelwood Exploitation by Rural Women: Impact on sustainable Environment in Ogun State, Nigeria. Journal of Agricultural Management and Rural Development. pp. 73-82.

Adhikari, B. (2002). Household Characteristics and Common Property Resource Management: A Model for Households Dependency on Local Commons. In: Proceedings of the Ninth Bennial Conference of the International Association for the Study of Common Property, Victoria Falls, Zimbabwe.

Baland, J.M. Platteau, J.P. (1996). Halting Degradation of Natural Resources. Is there a Role for Rural Communities? Clarendon Press, Oxford.

Baland, J.M. Bardhan, P. DAS S. Mookherjee, D. Rinki, S. (2004). The Environmental Impact of Poverty: Evidence from Firewood Collection in Rural Nepal. Paper Presented at the Tenth Biennial Conference of the International Association for the Study of Common Property (IASCP), Oaxaca Mexico, 9-13 August, 2004.

Department of Water Affairs and Forestry (DWAF), (2005). Pilot State of the Forest Report. A pilot report to test the national criteria and indicators. Institute of Natural Resource. Scottsville. Investigational Report Number: 253.

Ebe, F. E. (2006). Economic study of fuelwood marketing and consumption in Enugu State, Nigeria. A Ph.D research findings seminar presented to the department of agricultural economics, University of Nigeria, Nsukka.

Hassan, R. M. Mbuli, P., and Dlamini, C. (2002). Natural resource accounts for the state and Economic contribution of forests and woodland resources 
in Swaziland. Centre for Environmental Economics and Policy in Africa. University of Pretoria. CEEPA Discussion Paper Series.

Jande, J.A. (2005). Analysis of fuelwood consumption among the residents of Makurdi suburbs, Benue State. In: Environmental sustainability and conservation in Nigeria. Okoko E, Adekunle VAJ, Adeduntan SA (eds). Environmental conservation research team, Federal University of Technology, Akure, Nigeria. Pp 58-61.

Mainagwa, M. G. (2010). Fuelwood Makerts in Sub-Saharan Africa: Factors which Impede, and Incentives which will Accelerate their Development. $6(1): 36-48$.

Minibas, T. (1997). Forestry and Women keynote Address on Women in Forestry. In: proceedings of the XI World Resources Forestry Congress. $13^{\text {th }}-22^{\text {nd }}$ October, 1996. Antalya Vol. 8 pp. $59-61$.

Morgan, R. P. C. (1995). Soil Erosion \& Conservation. 2nd ed. Longman. UK. Prasad, G. and Visagie, E. 2005: Renewable energy technologies for poverty.

Onasanya A.S. (2005). "Women's participation in forestry/timber activities in ljebu north local government area, Ogun state Nigeria. Journal of Agricultural Management and Rural Development 2006 pp. 24-45.

Tee, N. T. Ancha, P. U. and Asue, J. (2009). Evaluation of fuelwood consumption and implications on the environment: a case study of Makurdi area in Benue state, Nigeria. Journal of Applied Biosciences 19: 1041 - 1048. University of Agriculture, Makurdi, Nigeria.

Williams, M. (2003). Deforestating the earth from Prehistory to Global Crisis. "American forests". University of Chicago Press. 